\title{
PENGARUH MODEL PEMBELAJARAN PROJECT BASED LEARNING (PjBL) TERHADAP HASIL BELAJAR IPA
}

\author{
Komang Ratna Mayuni ${ }^{1}$, Ni Wayan Rati ${ }^{2}$, Luh Putu Putrini \\ Mahadewi $^{3}$ \\ ${ }^{12}$ Jurusan PendidikanSekolahDasar, Fakultas IImu Pendidikan \\ ${ }^{3}$ Jurusan Teknologi Pendidikan, Fakultas IImu Pendidikan \\ Universitas Pendidikan Ganesha \\ Singaraja \\ e-mail: komang.ratna.mayuni@undiksha.ac.id ${ }^{1}$, niwayan.rati@undiksha.ac.id ${ }^{2}$, \\ Ipp-mahadewi@undiksha.ac.id ${ }^{3}$
}

\begin{abstract}
Abstrak
Penelitian ini dilakukan berdasarkan masalah sebagai berikut. 1) Saat pembelajaran sedang berlangsung, siswa jarang memperhatikan guru. 2) Kurangnya pengetahuan guru tentang modelmodel pembelajaran. 3) Siswa jarang melakukan percobaan dan diberikan proyek. Penelitian ini bertujuan untuk mengetahuipengaruh yang signifikan model pembelajaran project based learning (PjBL) terhadap hasil belajar IPA pada siswa kelas IV SD Gugus I Kecamatan Seririt Kabupaten Buleleng tahun pelajaran 2017/2018. Populasi penelitian ini adalah siswa kelas IV Gugus I Kecamatan Seririt Kabupaten Buleleng tahun pelajaran 2017/2018 yang berjumlah 85 orang. Sampel penelitian ini adalah20 orang siswa kelas IV di SD Negeri 3 Kalianget dan 22 orang siswa kelas IV di SD Negeri 1 Joanyar. Data dikumpulkan dengan tes berbentuk pilihan ganda. Data yang dikumpulkan dianalisis menggunakan analisis statistik deskriptif dan statistik inferensial (uji-t). Hasil penelitian ini menunjukan bahwa terdapat perbedaan yang signifikan hasil belajar IPA antara kelompok siswa yang dibelajarkan dengan menggunakan model pembelajaran project based learning (PjBL)dan kelompok siswa yang dibelajarkan dengan model konvensional. Rata-rata skor hasil belajar IPA siswa yang dibelajarkan dengan model project based learning ( $\mathrm{PjBL}$ )adalah 22,15 tergolong kriteria sangat tinggi. Rata-rata hasil belajar IPA siswa yang dibelajarkan dengan model konvensional adalah 17,21 yang berada pada kategori tinggi, dan $t_{\text {hitung }}=6,31, t_{\text {tabel }}=2,021$ pada taraf signifikan $5 \%$. Hal ini berarti bahwa $t_{\text {hitung }}>t_{\text {tabel }}$. Jadi model pembelajaran project based learning (PjBL)berpengaruh positif terhadap hasil belajar IPA siswa kelas IV Gugus I Kecamatan Seririt Kabupaten Buleleng tahun pelajaran 2017/2018.
\end{abstract}

Kata kunci: IPA, hasil belajar,PjBL

\section{Abstract}

This research was conducted based on several problems as follows. 1) The students rarely pay attention to the teacher. 2) Lack of the teacher's knowledge about learning models. 3) The students rarely do an experiments and projects during the lesson. This study aims to determine the effect is significant of model project-based learning ( $\mathrm{PjBL}$ ) against the learning outcomes science of student fourth grade primary schools district of Seririt, Bulelelng regency cluster I academic year 2017/2018. There were 85 students from all of fourth grade of Seririt district primary schools cluster Ichosen as the population of this study. The samples of this study were 20 students from SD Negeri 3 Kalianget and 22 students from SD Negeri 1 Joanyar. The data were collected through a test in the form of objective test. The data were analysed using both descriptive and inferential (t-test) statistical analysis. The result of this study showed that there was a significant effect on students' science achievement between students taught using project-based learning (PjBL) and students taught without using project-based learning (conventional teaching method). Mean score of experimental group was 22.15 while the control group achieved 17.21. Furthermore, $\mathrm{t}$ observed $=6.31, \mathrm{t}$ critical value $=2.021$ (significance

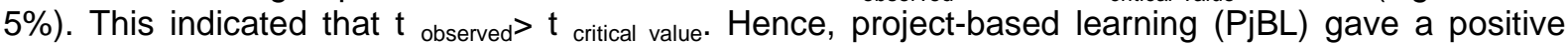
effect towards students' science achievement in fourth grade of Seririt district primary schools cluster I academic year 2017/2018.

Keywords: Science, learning outcomes, PjBL. 


\section{Pendahuluan}

Beragamnya mata pelajaran di sekolah bertujuan untuk meningkatkan kualitas sumber daya manusia dan meningkatkan mutu pendidikan di Indonesia.Salah satu mata pelajaran yang dimaksud adalah mata pelajaran Ilmu Pengetahuan Alam (IPA).IPA menekankan pada pemberian pengalaman untuk mengembangkan kemampuan siswa agar mampu menjelajahi dan memahami lingkungan alam secara ilmiah. Kemampuan ini akan terwujud apabila IPA berhasil menumbuhkan kemampuan berpikir logis, kritis, kreatif dan berinisiatif terhadap perubahan dan pembangunan.

Andana (2014) "IPA merupakan salah satu cabang ilmu pengetahuan yang memegang peranan penting dalam perkembangan ilmu pengetahuan dan teknologi". Dengan adanya pemaparan tersebut maka siswa akan memiliki keterampilan, dan sikap yang di perlukan untuk melanjutkan pendidikan ke jenjang yang lebih tinggi dan untuk menyesuaikan diri dengan perubahan-perubahan disekelilingnya.

Samatowa (2011:2) "mata pelajaran IPA di SD hendaknya membuka kesempatan untuk memupuk rasa ingin tahu anak didik secara alamiah". Hal tersebut akan membantu mereka untuk mengembangkan kemampuan bertanya dan mencari jawaban berdasarkan bukti serta mengembangkan cara berpikir ilmiah juga dapat memberikan pengalaman secara langsung.

Ada beberapa alasan pentingnya pembelajaran IPA di sekolah dasar menurut Sudana, dkk (2010:5), yaitu sebagai berikut. 1) IPA dapat membantu secara positif pada anak-anak untuk dapat memahami mata pembelajaran lain terutama bahasa dan matematika, 2) IPA di banyak negara, terutama pendidikan IPA di sekolah merupakan pendidikan terminal untuk anak-anak dan ini berarti hanya selama di SD itulah mereka dapat mengenal lingkungannya secara logis dan sistematis, 3) IPA SD benar-benar dapat menyenangkan.

Berdasarkan hasil observasi pada tanggal 13-14 Desember di Sekolah Dasar (SD) Gugus I Kecamatan Seririt Kabupaten Buleleng hasil belajar IPA masih rendah, hal ini disebabkan oleh proses pembelajaran yang masih belum sesuai dengan tujuan pembelajaran IPA di sekolah.Kompetensi tingkat keprofesionalan guru serta cara, teknik dan strategi guru dalam mengajar juga sangat berpengaruh dalam proses pembelajaran bisa berjalan dengan efektif dan efisien. Selain hal tersebut di atas pembelajaran IPA di kelas masih menggunakan metode ceramah dan penugasan hal ini menyebabkan pembelajaran IPA masih monoton dan kurang bervariasi, selain penggunan metode yang kurang bervariasi penggunaan media dan alat peraga yang belum banyak di terapkan dalam pembelajaran IPA sehingga siswa hanya berfikir abstrak mengenai pelajaran yang di sampaikan oleh guru.

Dalam proses pembelajaran siswa cenderung pasif karena siswa hanya menulis dan mendengarkan saja, siswa juga sulit untuk memahami konsep yang di berikan oleh guru karena siswa hanya menghafal pokok pembelajaran. Guru jarang memberikan percobaan kepada siswa yang semestinya dalam proses percobaan banyak manfaat yang dapat diterima oleh siswa salah satunya, siswa dapat menemukan langsung apa yang ia dapatkan selama proses percobaan, siswa banyak berkomunikasi dengan sesama anggota kelompok, siswa juga tidak hanya mencatat saja melainkan mengamati, mencoba, dan terlibat langsung dalam percobaan.

Hasil observasi tersebut didukung pula dengan hasil wawancara yang dilakukan kepada guru kelas IV SD Negeri 3 Kalianget dan guru kelas IV SD Negeri 1 Joanyar yang mengemukakan beberapa permasalahan saat mengajar di antaranya: (1) Saat pembelajaran sedang berlangsung, siswa jarang memperhatikan guru dan lebih sering bermain di dalam kelas.(2) Kurangnya pengetahuan guru tentang model-model pembelajaran. (3) Guru jarang melakukan percobaan dan memberikan siswa proyek, sehingga rasa ingi tahu siswa tentang pelajaran menjadi rendah. Kondisi demikian, akan berpengaruh terhadap hasil dan motivasi belajar siswa. Kondisi di atas diperkuat dengan hasil pencatatan dokumen yang dilakukan di seluruh SD Gugus I Kecamatan Seririt Kabupaten Buleleng. Berdasarkan pencatatan dokumen pada pembelajaran IPA, maka didapatkan nilai rata-rata UAS mata pelajaran IPA siswa kelas IV masih dibawah KKM. 
Mengacu pada permasalahan di atas, guru hendaknya lebih banyak menfariasikan pembelajaran di kelas, dan memperbanyak penggunaan model pembelajaran yang sesuai dengan kondisi siswa dan karakteristik materi pembelajaran IPA yang akan di belajarkan di kelas. Pada saat ini telah berkembang berbagai model pembelajaran inovatif untuk diterapkan dalam proses pembelajaran IPA di SD.

Salah satu inovasi model pembelajaran yang dimaksud yakni dengan menerapkan model Pembelajaran Project Based Learning. Kosasih (2016:96) menyatakan bahwa "Pembelajaran berbasis proyek (Project Based Learning) adalah model pembelajaran yang menggunakan proyek/kegiatan sebagai tujuannya". Selanjutnya, model pembelajaran ini juga dikemukakan oleh Nasution \& Rizal 2016 (dalam Dewi dkk, 2017) menyatakan bahwa, Project Based Learning adalah model pembelajaran yang berfokus pada konsep-konsep dan prinsip-prinsip utama (sentral) dari suatu disiplin, melibatkan siswa dalam kegiatan memecahkan masalah dan tugas-tugas bermakna lainnnya, memberi peluang siswa bekerja secara otonom mengkonstruk belajar mereka sendiri, dan puncaknya menghasilkan produk karya siswa bernilai, dan realistik.

Dari pendapat yang dikemukakan oleh kedua orang di atas dapat di simpulkan bahwa model pembelajaran Project Based Learning adalah model pembelajaran yang menggunakan proyek sebagai tujuannya dan melibatkan siswa dalam kegiatan memecahkan masalah dan tugas-tugas bermakna lainnnya, memberi peluang siswa bekerja secara otonom mengkonstruk belajar mereka sendiri, dan puncaknya menghasilkan produk karya siswa bernilai, dan realistik.

Model Pembelajaran Project Based Learning "memfokuskan pada aktivitas siswa yang berupa pengumpulan informasi dan pemanfaatannya untuk menghasilkan sesuatu yang bermanfaat bagi kehidupan siswa itu sendiri ataupun bagi orang lain, namun tetap terkait dengan KD dan kurikulum" (Kosasih, 2016:96).

Model Pembelajaran Project Based Learning menggunakan masalah sebagai langkah awal pembelajarannya, masalah yang dimaksud adalah berupa pernyataan yang akan dikaitkan dengan proses pembelajaran yang akan dicapai dan kemudian disajikan sebagai proyek, sesuatu yang harus di garap atau di kerjakan oleh siswa. Dengan demikian, akhir dari pembelajaran ini berupa suatu produk, kegiatan atau karya. Dalam proses pembelajaran siswa ikut terlibat langsung dalam pengerjaan proyek sehingga guru dapat mengembangkan keterampilan proses sains pada diri siswa seperti rasa ingin tahu, sikap ingin mendapatkan sesuatu yang baru, sikap tidak putus asa dan percaya diri.

Proyek dalam pembelajaran berbasis proyek tidak ditentukan oleh hasil belajar yang didapatkan oleh siswa saja, namun juga dilihat pada proses dan aktivitas siswa dalam proses pembelajaran sehingga akan berdampak pada meningkatnya hasil belajar siswa, dan siswa lebih banyak belajar mandiri dimana guru berperan sebagai pembimbing, fasilitator, motivator dan evaluator

Penggunaan model ini hendaknya mengikuti langkah-langkah dari model pembelajaran tersebut.Adapun langkah-langkah dari model pembelajaran project based learning yaitu: (1) Penentuan proyek.Siswa menentukan jenis kegiatan atau karya yang akan mereka kerjakan, sesuai dengan kebutuhan masing-masing. Minat, kemampuan, serta ketersediaan sarana dan prasarana harus menjadi pertimbangan siswa dalam langkah ini.Adapun tugas guru adalah mengarahkan pilihan-pilihan itu agar tetap berada pada koridor pembelajaran, tetap relevan dengan KD yang sedang dikembangkan. (2) Perencanaan proyek.Siswa merancang langkah-langkah kegiatan pelaksanaan proyek, dari awal sampai akhir penyelesaiannya. Berikut adalah langkah-langkah kegiatan pelaksanaan perancangan proyek (a) Pada tahap awal, berupa perencanaan alat, bahan, waktu yang diperlukan, dan hal-hal lainnya. Termasuk dalam tahap ini adalah pembagian tugas di antara mereka kalau proyek yang dimaksud adalah dilakukan secara berkelompok. (b) Pada tahap pelaksanaan, berupa perancangan inti kegiatan yang akan dilakukan siswa, termasuk menata kendala yang mungkin mereka hadapi beserta kemungkinan-kemungkinan cara mengatasinya. (c) Pada tahap akhir, berupa perencanaan tindak lanjut apabila proyek itu terselesaikan. Misalnya, berupa pameran, presentasi, diskusi kelas. (3) Penyusunan Jadwal.Di bawah bimbingan 
guru, Para siswa melakukan penjadwalan semua kegiatan yang telah dirancangnya.Jadwal tersebut menunjukan berapa lama proyek itu harus diselesaikan tahap demi tahap.Jadwal yang dimaksud disesuaikan dengan program yang tersedia pada guru itu sendiri, serta kesanggupan siswa di dalam menyelesaikan proyek yang telah di rancangnya. (4) Penyelesaian Proyek.Pada tahap ini siswa mengerjakan tugas sesuai dengan pembagain yang telah dirancang sebelumnya. Guru berperan untuk memotivasi, mengarahkan, mengoordinasikan sehingga kegiatan dan proyek siswa dapat memastikan penyelesaiannya dengan baik dan tepat waktu. Bersamaan dengan itu, guru perlu melakukan monitoring terhadap aktivitas siswa dalam rangka proses penilaian, sesuai dengan indikator-indikator yang telah ditetapkan, baik itu terhadap aspek kognitif, psikomotor, ataupun kognitifnya. (5) Menyampaian Hasil Kegiatan.Dalam pendekatan saintifik, langkah ini termasuk kedalam langkah mengomunikasikan.Bentuk penyampaianya bergantung pada proyek yang dihasilkan siswa.Dalam kegiatan ini pun siswa didorong untuk belajar mempertanggungjawabkan atas kejadian-kejadian yang telah dijalaninya. (6) Evaluasi Proses dan Hasil Kegiatan.Guru dan siswa melakukan refleksi terhadap serangkaian kegiatan yang telah mereka jalani beserta hasil-hasilnya. Pada tahap ini, siswa mendapat kesempatan mengemukakan pengalamannya, kesan-kesan, serta kesulitan-kesulitan yang mereka hadapi. Guru kemudian memberikan berbagai masukan dan pertimbanganpertimbangan terkait dengan kualitas kerja mereka.(Kosasih,2016).

Menurut Rusman (2017:410) kelebihan model pembelajaran berbasi proyek adalah sebagai berikut: (1) Meningkatkan motivasi belajar peserta didik untuk belajar, mendorong kemampuan mereka untuk melakukan pekerjaan penting, dan mereka perlu untuk di hargai. (2) Meningkatkan kemampuan pemecahan masalah. (3) Membuat peserta didik menjadi lebih aktif dan berhasil memecahkan problem-problem yang kompleks.(4) Meningkatkan kolaborasi. (5) Mendorong peserta didik untuk mengembangkan dan mempraktekan keterampilan komunikasi. (6) Meningkatkan kemampuan peserta didik dalam mengelola sumber. (7) Memberikan pengalaman kepada peserta didik pembelajaran dan praktik dalam mengorganisasi proyek, dan membuat alokasi waktu dan sumber-sumber lain seperti perlengkapan untuk menyelesaikan tugas. (8) Menyediakan pengalaman belajar yang melibatkan peserta didik secara kompleks dan dirancang untuk berkembamg sesuai dunia nyata. (9) Melibatkan para peserta didik untuk belajar mengambil informasi dan menunjukan pengetahuan yang dimiliki, kemudian di implementasikan dengan dunia nyata. (10) Membuat suasana belajar menjadi menyenangkan, sehingga peserta didik maupun pendidik menikmati proses pembelajaran.

Berdasarkan uraian yang telah dijabarkan, maka dilakukan penelitianyang bertujuan untuk menguji terdapat tidaknya perbedaan yang signifikan hasil belajar IPA antara kelompok siswa yang dibelajarkan dengan model pembelajaran project based learning dan kelompok siswa yang dibelajarakan dengan pembelajaran konvensional pada siswa kelas IV SD Gugus I Kecamatan Seririt Kabupaten Buleleng Tahun Pelajaran 2017/2018.

\section{Metode}

Jenis penelitian yang digunakan adalah penelitian eksperimen semu (Quasi Eksperiment).Penelitian eksperimen semu adalah penelitian yang dilakukan dengan memberikan perlakukan (treatmen) tertentu terhadap subjek penelitian yang bersangkutan. Desain penelitian yang digunakan adalah non-equivalent post-test only control group design. Dalam non-equivalent post-test only control group design terdapat dua kelompok yang dipilih secara rendom, kelompok pertama merupakan kelompok eksperimen sedangkan kelompok kedua merupakan kelompok kontrol.

Populasi dalam penelitian ini adalah kelas IV di gugus I Kecamatan Seririt Kabupaten Buleleng yang terdiri dari 4 SD yakni SD Negeri 1 Kalianget, SD Negeri 3Kalianget, SD Negeri 1Joanyar, SD Negeri 1Tangguwisia tahun pelajaran 2017/2018 yang terdiri dari 85 siswa.Teknik pengambilan sampel yang digunakan dalam penelitian ini adalah teknik random sampling. 
Untuk mengetahui apakah kemampuan siswa kelas IV masing-masing sekolah setara atau tidak, maka terlebih dahulu dilakukan uji kesetaraan dengan menggunakan ANAVA Satu jalur.

Berdasarkan uji ANAVA satu jalur diketahui bahwa kelas IV di gugus I Kecamatan Seririt Kabupaten Buleleng merupakan kelas yang setara.Dengan hasil $t_{\text {hitung }}<t_{\text {tabel }}$. Pada tahap ke dua, berdasarkan uji kesetaraan, maka sekolah yang lolos uji akan diundi secara acak dari sampel yang sudah lolos uji kesetaraan, untuk menentukan sekolah yang akan dijadikan sebagai tempat penelitian. Dari hasil undian diperoleh pasangan SD Negeri 3Kalianget dengan SD Negeri 1Joanyar.

Selanjutnya pada tahap ketiga, sekolah yang telah terpilih kembali diundi secara acak untuk menentukan kelas eksperimen dan kelas kontrol.Hasil pengundian menyatakan SD Negeri3Kalianget sebagai kelas eksperimen dan SD Negeri1Joanyar sebagai kelas kontrol.

Penelitian ini melibatkan variabel bebas dan variabel terikat. Pada penelitian ini, variabel bebas yang dilibatkan adalah penerapan model pembelajaran project based learningsedangkan variabel terikat yang dilibatkan dalam penelitian ini adalah hasil belajar IPA.

Hasil belajar yang dimaksud dalam penelitian ini adalah hasil belajar aspek kognitif. Hasil belajar ini diukur dengan metode tes dengan tes objektif dengan jumlah 30 butir soal. Setiap soal disertai dengan empat alternatif jawaban yang dipilih oleh siswa (alternatif a, b, c, dan d) setiap item diberikan skor 1 bila siswa menjawab dengan benar (jawaban dicocokkan dengan kunci jawaban) serta 0 untuk siswa yang menjawab salah.

Sebelum tes digunakan sebagai alatukur telah dilakukan validasi instrumenyang meliputi: uji validitas isi, uji validitas butir tes, uji reliabilitas tes, uji taraf kesukaran butir tes, dan uji daya beda.

Analisis pertama yaitu Uji Validitas isi adapun jumlah soal yang diuji coba berjumlah 40 butir tes berbentuk tes objektif yang sebelumnya sudah di uji judges dan dianalisis dengan perhitungan Gregory Berdasarkan perhitungan menurut Gregory, tes tersebut berada pada kategori validitas isi sangat tinggi yaitu berada pada rentangan 0,80-1,00. Selanjutnya dilakukan uji coba instrument kepada 87 siswa kelas I SD Negeri 1Kalianget, SD Negeri 3Kalianget, SD Negeri 1Joanyar dan SD Negeri 1Tangguwisia.

Analisis kedua uji validitas butir dengan rumus korelasi point biserial. Hasil rhitung dikonsultasikan dengan rtabel dengan taraf signifikansi $5 \%$. Berdasarkan hasil uji validitas item tes, dengan jumlah responden 87 siswa diperoleh 38 tes yang valid dari 40 butir tes yang di uji cobakan, 38 butir tes yang valid akan di digunakan sebagai post-test dengan jumlah butir soal 30

Analisis ketiga yaitu uji reliabilitas 34 butir soal yang sudah valid diuji reliabilitas dengan menggunakan Kuder Richadson 20 (KR-20).Berdasarkan perhitungan terhadap 38 butir tes diperoleh koefisien Kuder Richardson (KR-20) sebesar 0,83 yang berada pada rentangan $0,83<X \leq 0,80$ sehingga dapat disimpulkan bahwa tingkat reliabilitas tes tergolong tinggi.

Analisis keempat taraf kesukaran tes.Bermutu atau tidaknya butir-butir item tes hasil belajar pertama-tama dapat diketahui dari derajat kesukaran atau taraf kesulitan yang dimiliki oleh masing-masing butir item tersebut.Fernandes (dalam koyan, 2011:140) menyatakan, "tes yang baik adalah tes yang memiliki taraf kesukaran antara 0,25-0,75". Berdasarkan analisis data uji coba tes hasil belajar IPA dari 38 butir soal, didapatkan hasil uji tingkat kesukaran tes diperoleh 14 butir soal termasuk katagori mudah, 23 butir soal termasuk katagorisedang, dan 1 butir soal termasuk katagori sukar

Analisis ke lima adalah uji daya beda. Berdasarkan hasil uji daya beda pada 38 buti soal, didapatkan 1 butir soal termasuk daya beda sangat baik, 19 butir soal termasuk daya beda baik, 16 butir soal termasuk daya beda cukup baik, dan 2 butir soal termasuk daya beda kurang baik

Dalam penelitian ini, metode yang digunakan untuk mengumpulkan data adalah metode tes, dengan menggunakan tes obyektif. Tes obyektif digunakan pada saat post-test. Data yang telah dikumpulkan dianalisis dengan menggunakan statistik deskriptif dan statistic inferensial. Statistik deskriptif berfungsi untuk mengelompokkan data, memaparkan serta 
menyajikan hasil olahan.Statistik deskriptifyangdigunakan dalampenelitian ini yaitumean (rata-rata), standar deviasi dan varians.Sedangkan statistic inferensial berfungsi untuk menggeneralisasikan hasil penelitian yang dilakukan pada sampel bagipopulasi.Statistikin ferensial ini digunakan untuk menguji hipotesis melalui uji-t (polled varians) yang diawali dengan analisis prasyaratyaituuji normalitas sebaran datadanuji homogenitas.

\section{Hasil dan Pembahasan}

Rekapitulasi perhitungan data hasil penelitian tentang hasil belajar IPA siswa dapat dilihat pada Tabel 1.

Tabel 1. Rekapitulasi Hasil Perhitungan Hasil belajar IPA

\begin{tabular}{lll}
\hline Statistik Deskriptif & Kelompok Eksperimen & Kelompok Kontrol \\
\hline Mean (M) & 22,15 & 17,23 \\
Median (Md) & 22,40 & 17,21 \\
Modus (Mo) & 22,88 & 16,10 \\
Varians & 13,61 & 17,52 \\
Standar Deviasi & 3,68 & 4,18 \\
Skor Minimum & 13 & 10 \\
Skor Maximum & 29 & 26 \\
Rentangan & 3 & 3 \\
\hline
\end{tabular}

BerdasarkanTabel diatas, diketahui kelompok eksperimen memiliki mean $=22,15$, median $=22,40$ dan modus $=22,88$ yang berarti mean lebih kecil dari median dan median lebih kecil dari modus (Mo>Md>M).digambarkan.dalam grafik polygon membentuk kurva juling negative yang berarti sebagian besar skor cenderung tinggi. Adapun kurva disajikan pada Gambar1.

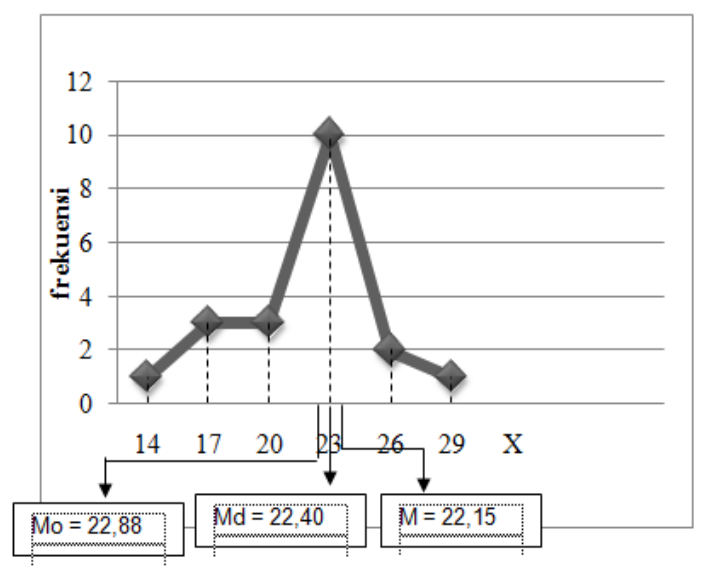

Gambar 1. Poligon Dara Hasil Belajar IPA Siswa Kelompok Eksperimen.

Berdasarkan grafik poligon data pemahaman konsep kelompok eksperimen di atas, grafik di atas adalah grafik juling negatif. Artinya, sebagian besar skor cenderung tinggi.Kecenderungan skor ini dapat dibuktikan dengan melihat frekuensi relatif pada tabel distribusi frekuensi.Frekuensi relatif skor yang berada di atas rata-rata lebih besar dibandingkan frekuensi relatif skor yang berada di bawah rata-rata.

Sedangkan kelompok kontrol memiliki mean $=17,23$, median $=17,21$, dan modus= 16,10yang berarti moduslebih kecil dari mediandan medianlebihkecildarimean 
$(\mathrm{Mo}<\mathrm{Md}<\mathrm{M})$.digambarkandalam grafik polygonmembentukkurva juling positif yang berarti sebagian besar skor cenderungrendah.Adapunkurva disajikan padaGambar2.berikut.

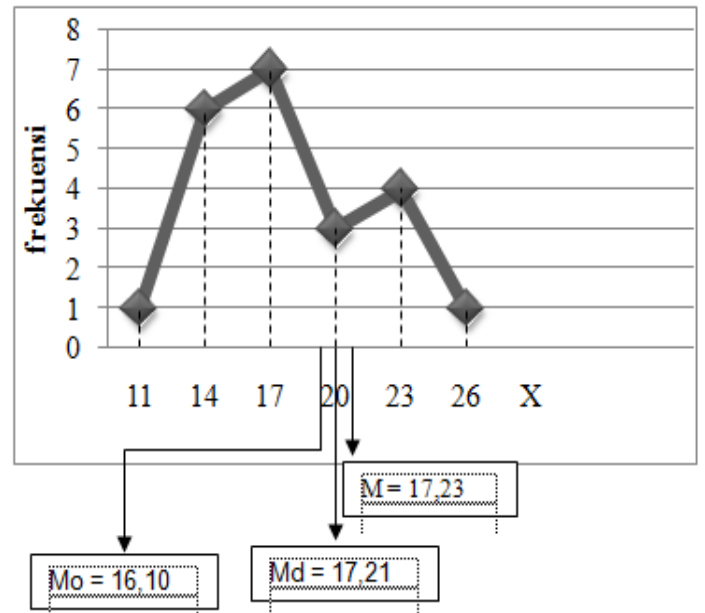

Gambar 2. Poligon Dara Hasil Belajar IPA Siswa Kelompok Kontrol.

Berdasarkan Grafik poligon data pemahaman konsep kelompok kontrol di atas, grafik di atas adalah grafik juling positif. Artinya, sebagian besar skor cenderung rendah. Kecenderungan skor ini dapat dibuktikan dengan melihat frekuensi relatif pada tabel distribusi frekuensi.Frekuensi relatif skor yang berada di atas rata-rata lebih kecil dibandingkan frekuensi relatif skor yang berada di bawah rata-rata.

Uji asumsi dilakukan terlebih dahulu sebelum uji hipotesis menggunakan uji-t.Uji asumsil tersebut meliputi uji normalitas dan uji homogenitas varians. Hasil uji normalitas sebaran data didapatkan harga $x 2_{\text {hitung }}$ hasil post test kelompok eksperimen sebesar 3,95dan $\mathrm{x} 2$ tabeldengan $(\mathrm{db})=5$ pada taraf signifikansi $5 \%$ adalah 11,07 . Hal ini berarti $\mathrm{x}^{2}$ hitung hasil post testkelompok eksperimen lebih kecil dari $x^{2}$ tabe $(3,95<11,07)$. Sehingga data hasilpost test kelompok eksperimen berdistribusi normal. Sedangkan $x^{2}$ hitung hasil post-test kelompok kontrol adalah7,08dan $x 2$ tabehasil post-test kelompok kontrol dengan ( $\mathrm{db}$ ) $=5$ pada taraf signifikansi $5 \%$ adalah 11,07 . Hal ini berarti $x^{2}$ hitung hasil post-testkelompok kontrol lebih kecil dari $x 2$ tabel $(7,08<11,07)$. Sehingga data hasil posttest kelompok kontrol berdistribusi normal.

Uji homogenitas varians dilakukan terhadap varians pasangan antar kelompok eksperimen dan kontrol.Uji yang digunakan adalah uji $\mathrm{F}$ dengan kriteria data homogen jika $f_{\text {hitung }}<f_{\text {tabel }}$. Berdasarkan hasil perhitungan uji homogenitas didapatkan harga $f_{\text {hitung }}$ sebesar 1,29 sedangkan $\mathrm{f}_{\text {tabel }}$ pada taraf signifikansi $5 \%$ adalah 2,09 Hal ini berarti $\mathrm{f}_{\text {hitung }}$ lebih kecil dari $f_{\text {tabel }}(1,29<2,09)$ sehingga dapat dinyatakan bahwa varians data hasil post-test kelompok eksperimen dan kontrol adalah homogen.

Berdasarkan hasil analisis uji asumsi yang meliputi uji normalitas dan uji homogenitas, diperoleh bahwa data hasil belajar IPA siswa kelompok eksperimen dan kelompok kontrol adalah normal dan homogen, sehingga pengujian hipotesis penelitian dengan uji-t dapat dilakukan.

Uji hipotesis dilakukan dengan menggunakan statistik uji-t dengan rumus polled varians. Kriteria pengujian adalah $\mathrm{H} 0$ ditolak jika $t_{\text {hitung }}>t_{\text {tabel. }}$. Pengujian dilakukan pada taraf signifikansi $5 \%$ dengan $\mathrm{db}=\mathrm{n}_{1}+\mathrm{n}_{2}-2$. Hasil perhitungn uji-t dapat dilihat dalam Tabel 2 . 
Tabel 2. Hasil Perhitungan Uji-t

\begin{tabular}{lllllll}
\hline Data & Kelompok & $\mathrm{N}$ & $\mathrm{X}$ & $\mathrm{s}^{2}$ & $\mathrm{t}_{\text {hit }}$ & $\mathrm{t}_{\text {tab }}$ \\
\hline Hasil & Eksperimen & 20 & 22,15 & 13,61 & 6,31 & 2,021 \\
belaja & Kontrol & 22 & 16,60 & 17,79 & & \\
r IPA & & & & & & \\
\hline
\end{tabular}

Berdasarkan Tabel hasil perhitungan uji-t diatas, diperoleh $t_{\text {hit }}$ sebesar6,31. Sedangkan $t_{\text {tab }}$ dengan $d k=20+22-2=40$ dan taraf signifikansi 5\% adalah 2,021 . Hal ini berarti, $t_{\text {hit }}$ lebih besar dari $t_{\text {tab }}\left(t_{\text {hit }}>t_{\text {tab }}\right.$ ), sehingga $H_{0}$ ditolak dan $H_{1}$ diterima. Dengan demikian, dapat diinterpretasikan bahwa terdapat perbedaan yang singnifikan hasil belajar IPA antara kelompok siswa yang dibelajarkan dengan model pembelajaran project based learning dan kelompok siswa yang dibelajarkan dengan pembelajaran konvensional pada siswa kelas IV SD Gugus I Kecamatan Seririt Kabupaten Buleleng Tahun Pembelajaran 2017/2018.

Hasil penelitian ini menunjukkan bahwa hasil belajar kelas eksperimen berbeda dengan hasil belajar kelas kontrol. Pada penelitian ini kedua sampel yang memiliki kemampuan yang setara, namun setelah diberikan perlakuan dengan memberikan model project based learning diperoleh hasil kompetensi pengetahuan yang berbeda dilihat dari $\bar{X}$ siswa yang mengikuti pembelajaran menggunakan model project based learning lebih tinggi dibandingkan dengan $\bar{X}$ siswa yang mengikuti pembelajaran konvensional. Pengaruh yang signifikan antara siswa yang mengikuti model pembelajara project based learning dan siswa yang mengikuti pembelajaran konvensional disebabkan oleh perbedaan perlakuan pada proses pembelajarannya.

Pada kelompok eksperimen yang diberikan perlakuan dengan model Pembelajaran project based learning, berjalan dengan optimal. Dalam proses pembelajarannya, siswa terlihat semangat dan sangat antusias pembuatan proyek yang diberikan oleh guru. Pada kelompok eksperimen pembelajaran yang di padupadankan dengan pemberian proyek menjadikan pembelajaran menjadi lebih menarik minat siswa dalam mengikuti pembelajaran, khususnya pada aktivitas mengomunikasikan yang pada awalnya siswa nampak pasif pada aktivitas mengomunikasikan. Namun setelah diberikan perlakuan, aktivitas siswa menjadi tinggi dan semua siswa ikut terlibat aktif dan dengan diberikannya proyek yang meningkatkan kreatif siswa seperti proyek box mini, PanPel, Mind maping, dan peta konsep siswa menjadi lebih tertarik dan siswa yang awalnya takut dalam menyampaikan pendapat atau menyampaikan hasil diskusi menjadi berani dalam menyampaikan pendapatnya. Dengan pemberian proyek siswa menjadi lebih kompetitif, kreatif dan terfokus dalam mengikuti pembelajaran.

Berbeda halnya pada kelompok kontrol, pembelajaran yang berlangsung kurang optimal.Dalam langkah pembelajaran yang menggunakan pendekatan saintifik khususnya pada kegiatan mengomunikasikan siswa selalu memerlukan bimbingan sehingga pembelajaran menjadi kurang efektif dan tidak semua siswa dapat terlibat dalam aktivitas mengomunikasikan, serta keterampilan siswa dalam mengkomunikasikan juga masih sangat kurang sehingga siswa yang masih tidak paham ataupun masih mempunyai jawaban yang salah tidak mendapat klarifikasi dari guru.

Temuan penilitian menunjukkan bahwa model project based learning berpengaruh positif terhadap hasil belajar IPA siswa dengan kecenderungan sebagian besar skor siswa tinggi, hal tersebut di sebabkan oleh beberapa hal dianataranya sebagai berikut

Pertama menumbuhkan motivasi. Hal ini dapat dilihat pada saat guru memberikan proyek siswa sangat termotivasi untuk mengerjakan proyek yang di berikan oleh guru menjadi proyek yang menarik, hal ini senada dengan pendapat Moursund (dalam Wena, 2010:147) Pembelajaran berbasi proyek dapat meningkatkan motivasi belajar siswa terbukti dari beberapa laporan penelitian tentang pembelajaran berbasis proyek yang menyatakan bahwa siswa sangat tekun, berusaha keras untuk menyelesaikan proyek, siswa merasa lebih 
bergairah dalam proses pembelajaran, dan keterlambatan dalam proses pembelajaran sangat kurang.

Kedua, pembelajaran ini melatih siswa untuk berpikir kreatif dan aktif.Winkel (dalam Susanto, 2013:8) menyatakan bahwa "melalui produk dapat diselidiki apakah dan seberapa jauh tujuan intruksional telah tercapai.Semua tujuan itu merupakan hasil belajar yang seharusnya diperoleh siswa". Hal ini dapat diamati pada saat kegiatan diskusi kelompok dalam memecahkan masalah yang berkaitan proyek yang diberikan. Dalam diskusi kelompok dapat terjalin kerjasama antar siswa sehingga siswa terlibat aktif dalam pembelajaran dan memahami materi yang sedang dipelajari. Selain itu, secara tidak langsung siswa belajar untuk saling memahami dan menghormati pendapat orang lain. Dengan demikian, kerjasama dalam diskusi kelompok dan pengerjaan proyek dapat menjadikan siswa lebih memahami materi dan meningkatkan pemahaman konsep hal ini senada dengan pendapat Rusman (2017:410) bahwa proyek mendorong peserta didik untuk mengembangkan dan mempraktekan keterampilan komunikasi.

Ketiga, dalam model pembelajaran project based learning peran guru dalam pembelajaran hanya sebagai fasilitator dan motivator. Peran guru sebagai fasilitator terlihat pada saat memberikan tanggung jawab kepada siswa untuk menyelesaikan proyek yang dibuat sesuai dengan jadwal proyek yang sudah di sepakati. Sedangkan peran guru sebagai motivator tercermin pada proses pembelajaran guru selalu memberikan motivasi bagi siswa untuk dapat menemukan nilai yang terkandung dalam proyek yang sedang dikerjakan siswa dan selanjutnya siswa dimotivasi untuk mengaplikasikan proyek yang sudah dibuat.

Berbeda halnya dengan kelas yang menggunakan model pembelajaran konvensional.Pembelajaran knovensional, guru cenderung lebih aktif sebagai sumber informasi bagi siswa dan siswa cenderung pasif dalam mengikuti pembelajaran.Kepasifan siswa menjadikan komunikasi yang terjalin hanya komunikasi satu arah yaitu antara guru dengan siswa. Pernyataan tersebut sependapat dengan Rasana (2009:21) menyatakan bahwa "Pembelajaran konvensional merupakan sebuah model pembelajaran yang ditandai dengan pengalaman-pengalaman yang berkaitan dengan konsep yang akan dipelajari, dilanjutkan dengan pemberian informasi oleh guru, tanya jawab, pemberian tugas oleh guru, pelaksanaan tugas oleh siswa sampai pada akhirnya guru merasa bahwa apa yang telah diajarkan dimengerti oleh siswa". Perbedaan tersebut dapat memberikan dampak yang berbeda pula terhadap hasil belajar IPA antara pembelajaran yang menggunakan model pembelajaran project based learning dengan pembelajaran konvensional. Dengan demikian, dapat disimpulkan bahwa model pembelajaran project based learning berpengaruh positif terhadap hasil belajar IPA siswa kelas IV Sd Negeri 3 Kalianget Kecamatan Seririrt Kabupaten Buleleng Tahun Pelajaran 2017/2018.

Temuan hasil penelitian di atas sesuai dengan temuan sebelumnya. Temuan penelitian tersebut antara lain sebagai berikut. Sandi Dewi (2013), yang menyebutkan bahwa penerapan model pembelajaran project based learning pengaruh positif terhadap hasil belajar IPA. Kamayani, I.A, Diah dkk (2013) menyatakan bahwa hasil penelitian menunjukan bahwa: (1) hasil belajar IPA siswa kelompok eksperimen tergolong sangat tinggi, (2) hasil belajar IPA siswa kelompok kontrol tergolong tinggi dan (3) terdapat perbedaan yang signifikan anatara hasil belajar IPA siswa kelas IV semester genap SD Gugus IX Kecamatan Buleleng antara siswa yang dibelajarkan dengan menggunakan model pembelajaran Project Based Learning berbantuan media tiga dimensi dan model pembelajaran konvensional

\section{Simpulan dan Saran}

Berdasarkan hasil penelitian dan pembahasan di atas, dapat disimpulkan bahwa dalam penelitian ini terdapat perbedaan yang signifikan hasil belajar IPA antara siswa yang dibelajarkan dengan model pembelajaran project based learning dengan kelompok siswa yang dibelajarkan menggunakan model pembelajaran konvensional di kelas IV SD di Gugus I Kecamatan Seririrt Kabupaten Buleleng Tahun Pelajaran 2017/2018. Hal ini ditunjukkan 
pada hasil hipotesis uji-t yang diketahui bahwa $t_{\text {hitung }}=6,31>t_{\text {tabel }}=2,021$ berarti $\mathrm{H}_{0}$ ditolak dan $\mathrm{H}_{1}$ diterima.

Berdasarkan hasil temuan tersebut, dapat disimpulkan bahwa model pembelajaran project based learning berpengaruh positif terhadap hasil belajar IPA pada siswa kelas IV SD gugus I Kecamatan Seririt Kabupaten Buleleng Tahun Pelajaran 2017/2018.

Berdasarkan kesimpulan yang telah diuraikan di atas, dapat diajukan beberapa saran sebagai berikut.(1) Bagi guru, hasil penelitian ini menunjukkan bahwa terdapat pengaruh yang positif model pembelajaran project based learning terhadap hasil belajar IPA siswa. Untuk itu, para guru hendaknya dapat menerapkan suatu model pembelajaran inovatif dan menekankan pada keaktifan siswa serta suasana belajar yang menyenangkan dan guru dalam menyampaikan materi pelajaran di kelas hendaknya lebih berinovasi dalam memilih model pembelajaran yang mana model pembelajaran yang dipilih nantinya mampu mengatasi kebutuhan belajar dan karakteristik siswa. (2) Bagi siswa, dengan diterapkannya model pembelajaran project based learning dalam penelitian ini, diharapkan siswa menjadi lebih aktif dalam mengikuti proses pembelajaran serta mampu membangun pengetahuannya sendiri. (3) Bagii kepala sekolah, hendaknya ikut memperkenalkan dan memberikan dorongan bagi guru-guru untuk menerapkan model-model pembelajaran inovatif yang dapat digunakan dalam meningkatkan kualitas pembelajaran salah satunya adalah model pembelajaran project based learning. (4) Bagi peneliti lain, hasil belajar IPA siswa dapat diteliti dalam penelitian ini hanya terbatas pada hasil belajar pada ranah kognitif. Hendaknya untuk memperoleh hasil belajar siswa yang lebih komperhensif dalam pembelajaran maka perlu diadakan penelitian sejenis yang tidak hanya menyelidiki hasil belajar pada ranah kognitif tetapi juga mencangkup ranah afektif dan psikomotor siswa. Peneliti lain yang akan mengadakan penelitian lebih lanjut tentang model pembelajaran project based learning dengan pemberian proyek dalam bidang pelajaran agar memperhatikan kendala-kendala yang dialami dalam penelitian ini sebagai bahan pertimbangan untuk perbaikan dan penyempurnaan penelitian yang akan dilaksanakan.

\section{Daftar Rujukan}

Agustini, Eka dkk.2015."Pengaruh Model Pembelajaran VCT Terhadap Hasil Belajar Ranah Afektif Mata Pelajaran PKn Siswa".e-journal PGSD Undiksha. Vol.3 No. 1.

Chyntia Dewi, Ni Pt, dkk. 2017 "Pengaruh Model Pembelajaran Project Based Learning Berbasis Outdoor Study Terhadap Hasil Belajar IPA Siswa Kelas V".e-Journal PGSD Universitas Pendidikan Ganesha.Tersedia Pada https://ejournal.undiksha.ac.id/index.php/JJPGSD/article/download/10738/6844. (dia kses tanggal 7 Desember 2017)

Edi Ananda, I Md. 2014."Pengaruh Model Pembelajaran Berbasis Proyek Terhadap Hasil Belajar IPA Siswa Kelas IV SD Di Gugus V Kecamatan Tegallalang".e-Journal PGSD Universitas Pendidikan Ganesha.Tersedia Padahttp://download.portalgaruda.org/article. php?article=105329\&val=1342. (diakses tanggal 7 Desember 2017)

Kosasih, E. 2016. Strategi Belajar dan Pembelajaran Implementasi Kurikulum 2013. Bandung: Yrama Widya.

Koyan, I Wayan. 2011. Asesmen dalam Pendidikan. Singaraja: Universitas Pendidikan Ganesha.

Rasana, I Dewa Putu Raka.(2009). Laporan Sabbatical Leave; Model-model Pembelajaran. Singaraja: Universitas Pendidikan Ganesha. 
Rusman. 2017. Belajar Dan Pembelajaran Berorientasi Standar Proses Penidikan. Jakarta: PT Kharisma Putra Utama.

Samatowa, Usman. 2011. Pembelajaran IPA di Sekolah Dasar. Jakarta: PT Indeks.

Sudana, Dewa Nyoman dkk. 2016. Pendidikan IPA SD. Singaraja: Universitas Pendidikan Ganesha Press.

Susanto, Ahmad. 2013. Teori Belajar \& Pembelajarn di Sekolah Dasar. Jakarta: Kencana Prenada Media Group.

Wena, Made. 2010. Strategi Pembelajaran Inovatif Kontemporer Suatu Tinjauan Konseptual Operasional. Jakarta: PT Bumi Aksara. 